\title{
TINJAUAN KORELASI ANTARA KEMAMPUAN KONEKSI MATEMATIS DAN SELF-REGULATED LEARNING MATEMATIKA SISWA YANG PEMBELAJARANNYA MELALUI LEARNING CYCLE 5E
}

\author{
Sumarni \\ Program Studi Pendidikan Matematika, Universitas Kuningan, Jawa Barat. \\ e-mail: marni_39@yahoo.com
}

\begin{abstract}
This article examines the crelation between mathematical connection ability and selfregulated learning (SRL) mathematics students through the Learning Cycle 5E (LC 5E). In this case, the mathematical connection ability include aspects (1) Understanding the relationships between concepts or mathematical rules; (2) Implement the relationships between concepts or mathematical rules with topics other disciplines; and (3) Understanding the relationships between concepts or rules of mathematics with applications in everyday life. Indicators SRL mathematics include: (1) Demonstrate initiative in learning mathematics; (2) Diagnosing needs in learning mathematics; (3) Setting a target / goal of learning; (4) To monitor, regulate and control study; (5) Seeing difficulty as a challenge; (6) Utilize and search for relevant learning resources; (7) Choose and implement learning strategies; (8) Evaluate learning process and results; and (9) Self efficacy. LC 5E is a learning model that consists of five stages: (1) engagement, (2) exploration, (3) explanation, (4) elaboration, and (5) evaluation. This article is based on research conducted on 35 students of class VII one junior high school in West Bandung regency. The results show there is corelation between mathematical connection ability and SRL mathematics students. Students with high mathematical connection ability tend to have high SRL mathematics too and students with low mathematical connections ability tend to have low SRLmathematics too.
\end{abstract}

Keywords: mathematical connection ability, self-regulated learning, learning cycle $5 \mathrm{E}$

\section{PENDAHULUAN}

Matematika mempunyai peranan penting dalam kehidupan sehari-hari dan perkembangan ilmu pengetahuan dan teknologi. Oleh karena itu, pembelajaran matematika harus diarahkan untuk memenuhi kebutuhan masa kini dan kebutuhan masa yang akan datang (Sumarmo, 2013).

Matematika dalam kurikulum pendidikan di Indonesia adalah mata pelajaran yang wajib dipelajari oleh siswa dari tingkat pendidikan dasar, menengah hingga perguruan tinggi. Sumarmo (2013) mengemukakan bahwa pembelajaran matematika hendaknya mengutamakan pada pengembangan daya matematik (mathematical power) siswa yang meliputi: kemampuan menggali, menyusun konjektur dan menalar logis, menyelesaikan masalah yang tidak rutin, menyelesaikan masalah 
(problem solving), berkomunikasi secara matematika dan mengaitkan ide matematika dengan kegiatan intelektual lainnya (koneksi matematis).

Namun kenyataannya masih banyak siswa yang menganggap bahwa matematika adalah mata pelajaran yang menakutkan dan sulit untuk dipahami serta terlalu banyak rumus. Pada dasarnya matematika merupakan ilmu yang terstruktur, sehingga dalam belajar matematika untuk memahami suatu konsep siswa harus mengaitkan konsep yang satu dengan konsep yang lainnya. Selain itu, perubahan paradigm belajar matematika dan sesuai dengan kebutuhan serta perkembangan IPTEK, menuntut siswa juga harus mampu menyelesaikan soal matematika yang berkaitan dengan aplikasi dalam kehidupan sehari-hari serta mampu menyelesaikan soal yang menerapkan hubungan antar konsep atau aturan matematika dengan topik disiplin ilmu lain. Berdasarkan hal tersbut siswa dalam belajar matematika harus meemiliki kemampuan koneksi matematis yang baik. Melalui koneksi saat mempelajari konsep matematika siswa dapat menghubungkan konsep-konsep matematika yang telah dipelajari sebagai pengetahuan dasar untuk memahami konsep yang baru, sehingga siswa tidak mengalami kesulitan dalam mempelajari matematika.

Selama ini masih banyak siswa yang belajar matematika jika hanya ada PR atau jika disuruh oleh orang tuanya, masih banyak yang memanfaatkan waktunya untuk bermain game dan gadget dibandingkan menggunakan waktunya untuk belajar, banyak siswa yang datang ke sekolah tanpa persiapan mempelajari materi di rumah terlebih dahulu. Hal tersebut menunjukkan bahwa siswa kurang berinisiatif untuk belajar sendiri tanpa bimbingan dari guru di sekolah. Siswa juga banyak mengalami kesulitan dalam menyelesaikan soal yang berbentuk soal cerita yang merupakan soal aplikasi konsep matematika dalam kehidupan sehari-hari dan soal yang menerapkan konsep matematika dalam ilmu disiplin lain seperti fisika dan biologi. Namun yang sangat disayangkan ketika mereka menemui kesulitan dalam menyelesaikan soal tersebut, banyak dari mereka yang membiarkan saja (tidak mempelajarinya lebih dalam), sehingga menyebabkan mereka tidak mengetahui penyelesaian dari soal tersebut dan menganggap matematika sulit.

Berdasarkan pemaparan di atas, hal tersebut menunjukkan bahwa masih banyak siswa yang memiliki pengaturan diri dalam belajar yang kurang baik. Pengaturan diri dalam belajar disebut dengan Self-Regulated Learning (SRL). SRL adalah kemampuan siswa untuk mengatur diri dalam belajar. SRL dalam belajar matematika memiliki peran penting dalam meningkatkan kualitas dan kuantitas diri dalam belajar. SRL menempatkan pentingnya untuk mengatur dan mengendalikan diri 
sendiri, terutama bila menghadapi tugas. Hal ini sesuai dengan yang diungkapkan Sumarmo (2013) bahwa SRL merupakan proses perancangan dan pemantauan diri yang seksama terhadap proses kognitif dan afektif dalam menyelesaikan suatu tugas akademik. Apabila siswa mempunyai SRL yang tinggi, siswa tersebut cenderung belajar lebih baik. Hal ini didukung oleh hasil penelitian Hargis (Sumarmo, 2013) bahwa individu yang memiliki SRL cenderung belajar lebih baik, mampu memantau, mengevaluasi dan mengatur belajarnya secara efektif, menghemat waktu dalam menyelesaikan tugasnya, mengatur kegiatan dan waktu belajar secara efisien dan memperoleh skor yang tinggi dalam sains.

Salah satu model pembelajaran yang memfasilitasi pengembangan kemampuan koneksi dan SRL matematika adalah Learning Cycle 5E. Tahap-tahap yang terdapat pada LC 5E, yaitu sebagai berikut: (1) Tahap engagement, bertujuan mempersiapkan diri siswa, dengan cara menggali minat dan rasa ingin tahu siswa tentang pokok bahasan matematika yang akan diajarkan. Menggali minat dan rasa ingin tahu siswa dengan mengaitkan materi yang telah dimiliki siswa; (2) Tahap exploration, siswa diberi kesempatan untuk bekerja sama dalam kelompokkelompok kecil agar terjadi tukar pikiran antar siswa; (3) Tahap explanation, guru mendorong siswa untuk menjelaskan ide yang telah mereka dapatkan, lalu diwujudkan dalam presentasi kelompok; (4) Tahap elaboration, siswa dapat mengaplikasikan ide serta gagasannya ke dalam menyelesaikan latihan soal; (5) Tahap evaluation, dilakukan evaluasi pada siswa dengan mengoreksi hasil pekerjaan siswa dan menyimpulkan pelajaran yang telah diberikan (Lorsbach, 2002). Melalui tahap-tahap tersebut kemampuan koneksi matematis dan SRL siswa dapat dikembangkan.

Berdasarkan pemaparan tersebut, penulis tertarik untuk mengkaji asosiasi antara kemampuan koneksi matematis dan self-regulated learning matematika siswa melalui learning cycle 5E. Melalui kajian korelasi antara kemampuan koneksi matematis dan self regulated learning matematika siswa memalui learning cycle $5 E$ diharapkan dapat memberikan manfaat bagi: (a)Siswa dapat berlatih dan mengembangkan Self-regulated learning matematika untuk mengembangkan kemampuan koneksi matematis. (b) Guru yang terlibat dalam penelitian ini dapat memperoleh wawasan tentang penerapan Learning Cycle 5E.(c) hasil kajian ini dapat dijadikan sumber bagi peneliti selanjutnya untuk mengembangkan kajian dalam ruang lingkup yang lebih luas. (d) hasil kajian ini dapat menjadi sumbangan pemikiran baru bagi dunia pendidikan, agar kualitas pendidikan dapat ditingkatkan lagi. memberikan informasi tentang kajian korelasi antara kemampuan koneksi matematis dan self-regulated learning matematika siswamelaluiLearning Cycle 5E. 
KAJIAN TEORI

\section{Learning Cycle 5E}

Model pembelajaran LC

5Eadalah model pembelajaran yang memberikan kesempatan kepada siswa untuk mengoptimalkan kemampuan matematis siswa dalam proses pembelajaran. Model pembelajaran LC 5E terdapat tahap-tahap kegiatan (tahap) yang diorganisasikan sedemikian rupa, sehingga siswa dapat mencapai kompetensi-kompetensi yang menjadi tujuan pembelajaran.

\section{Proses pembelajaran} menggunakan LC 5E guru berperan sebagai motivator dan fasilitator yang mengelola tahapan kegiatan pembelajaran, dimulai dari perencanaan pembelajaran (terutama perangkat pembelajaran), pelaksanaan pembelajaran (terutama pemberian pertanyaan-pertanyaan arahan dan proses bimbingan) dan evaluasi. LC 5E terdiri atas lima tahap yaitu (a) pembangkit minat (engagement), (b) eksplorasi (exploration), penjelasan (explanation), (d) elaborasi (elaboration), dan (e) evaluasi (evaluation) (Lorsbach, 2002; Bybee et al, 2006; Madu \& Amaechi, 2012; Ergin, 2012). Kelima tahap tersebut dijabarkan sebagai berikut.

\section{(a) Tahap Pembangkit Minat (Engagement);}

Guru mengajukan masalah untuk mendapat perhatian siswa. Tahap ini diikuti dengan asesmen pengetahuan awal siswa pada topik yang akan dipelajari. Guru menginformasikan kepada siswa mengenai tujuan pembelajaran yang akan dilakukan.
Siswa mengingat kembali pengetahuan yang telah mereka ketahui, dan pengetahuan tersebut diperlukan mereka untuk diterapkan dalam pembelajaran. Guru mengajukan masalah kepada siswa untuk dieksplorasi pada tahap eksplorasi. Tahap ini merupakan titik awal pembelajaran dimulai.Untuk mengevaluasi tahap engagement, guru mengajukan pertanyaan yang spesifik pada topik yang ada untuk menentukan pengetahuan awal siswa.Siswa menjawab secara lisan.

\section{(b) Tahap Eksplorasi (Exploration);}

Tahap eksplorasi merupakan tahap ke dua dari LC 5E.Pada tahap eksplorasi dibentuk kelompok-kelompok kecil yang terdiri 5-6 siswa dalam satu kelompok. Pada tahap ini siswa diberi kesempatan untuk bekerja sama dalam kelompok tanpa pembelajaran langsung dari guru. Pada tahap ini guru berperan sebagai motivator dan fasilitator. Tujuan dari tahap eksplorasi adalah agar siswa mengumpulkan data yang dapat siswa gunakan untuk menyelesaikan masalah yang telah diajukan. Guru secara spesifik meminta siswa untuk (1) berpikir dengan bebas tetapi sesuai dengan tujuan pembelajaran; (2) mencari alternatif untuk permasalahan yang diajukan pada tahap engagement melalui diskusi dengan teman satu kelompok; (4) mencatat hasil observasi dan ide mereka; (5) memberikan pendapat dalam diskusi kelompok. Untuk mengevaluasi tahap eksplorasi, guru menanyakan kepada siswa mengenai pertanyaan: (1) bagaimana data dikumpulkan oleh 
siswa? ; (2) apakah prosedur yang dilakukan benar? ;(3) bagaimana pencatatan data yang telah dikumpulkan? ; (4) apakah sudah tertib/rapi?

\section{(c) Tahap}

(Explanation);

Penjelasan

\section{(d) Explanation}

merupakan

\section{tahap ke tiga dalam LC 5E.}

Pada tahap ini, guru memfasilitasi dan mendorong siswa untuk menjelaskan konsep dengan kalimat/pemikiran sendiri, meminta bukti dan klarifikasi atas penjelasan siswa dan saling mendengar secara kritis penjelasan antarsiswa atau guru. Dengan adanya diskusi tersebut, guru memberi definisi dan penjelasan tentang konsep yang dibahas dengan menggunakan penjelasan siswa terdahulu sebagai dasar diskusi. Untuk mengevaluasi tahap explanation, guru mengajukan pertanyaan kepada siswa mengenai proses pengumpulan data dan penggunaan data dalam penjelasan dan penarikan kesimpulan. Guru juga mengajukan pertanyaan pada bagian awal untuk menentukan pemahaman siswa.

\section{(e) Tahap}

Elaborasi

(Elaboration); Guru memberi siswa informasi baru yang merupakan perluasan dari apa yang telah mereka pelajari pada tahap sebelumnya. Pertanyaan yang diajukan pada tahap ini memungkinkan siswa untuk: (1) menerapkan definisi baru, menjelaskan dan menampilkan dalam bentuk baru tetapi dalam situasi yang sama; (2) menggunakan informasi sebelumnya untuk mengajukan pertanyaan, mengajukan solusi, membuat keputusan; (3) memaparkan alasan kesimpulan berdasarkan fakta; (4) mencatat observasi dan menjelaskannya; (5) memeriksa pemahaman satu sama lain. Evaluasi pada tahap elaboration, guru memberikan beberapa pertanyaan yang sebenarnya merupakan pertanyaan evaluasi.

(f) Tahap evaluasi (Evaluation); Evaluasi merupakan tahap terahkir dalam LC 5E. Pada tahap evaluasi, guru dapat mengamati pengetahuan atau pemahaman siswa dalam menerapkan konsep baru. Siswa dapat melakukan evaluasi diri dengan mengajukan pertanyaan terbuka dan mencari jawaban yang menggunakan observasi, bukti, dan penjelasan yang diperoleh sebelumnya. Hasil evaluasi ini dapat dijadikan guru sebagai bahan evaluasi tentang proses penerapan LC 5E sudah berjalan dengan sangat baik, cukup baik, atau masih kurang.

\section{Koneksi Matematis}

Koneksi berasal dari kata connection dalam Bahasa Inggris yang diartikan hubungan.Koneksi dalam kaitannya dengan matematika yang disebut dengan koneksi matematis dapat diartikan sebagai keterkaitan secara internal dan eksternal.Keterkaitan secara internal adalah keterkaitan antara konsepkonsep matematika yaitu berhubungan dengan matematika itu sendiri.Sedangkan, keterkaitan secara eksternal, yaitu keterkaitan antara 
matematika dengan kehidupan seharihari (Sumarmo, 2013).

Menurut NCTM (1989), terdapat dua tipe koneksi matematis, yaitu modeling connections dan mathematical connections. Modeling connections adalah hubungan antara situasi masalah yang muncul di dalam dunia nyata atau di dalam disiplin ilmu lain dengan representasi matematisnya. Sedangkan, mathematical connections adalah hubungan antara dua representasi yang ekuivalen dan antara proses penyelesaian dari masing-masing representasi.

Dalam penelitian yang dilakukan peneliti merumuskan kemampuan koneksi matematis, meliputi: (1) Memahami hubungan antar konsep atau aturan matematika; Menerapkan hubungan antar konsep atau aturan matematika dengan topik disiplin ilmu lain; dan (3) Memahami hubungan antar konsep atau aturan matematika dengan aplikasi dalam kehidupan sehari-hari.

\section{Self-Regulated Learning(SRL)}

SRL adalah proses kognitif mulai dari menghadirkan informasi atau instruksi, memproses dan mengintegrasikan pengetahuan dan mengulang informasi (Schunk, 2002). Selanjutnya, Bandura (Santrock, 2007) SRL adalah suatu strategi yang digunakan oleh individu dalam mencapai tujuan tertentu. Dengan demikian, SRL didefinisikan sebagai cara bagaimana seseorang merencanakan, mengontrol, dan mengarahkan aspekaspek proses kognitif dan perilakunya demi mencapai prestasi terbaiknya dalam kegiatan belajar. Darr \& Fisher (2004) menyatakan bahwa siswa yang memiliki SRL adalah siswa yang secara aktif bisa memaksimalkan kesempatan dan kemampuannya untuk belajar.Mereka tidak hanya mampu mengontrol metakognisinya tetapi juga mengembangkan kemandirian sikap dan perilaku serta sumber daya yang dibutuhkan untuk meningkatkan hasil pembelajaran yang positif.

Studi temuan Hargis (Sumarmo, 2013) bahwa individu yang memiliki SRL cenderung belajar lebih baik, mampu memantau, mengevaluasi dan mengatur belajarnya secara efektif, menghemat waktu dalam menyelesaikan tugasnya, mengatur kegiatan dan waktu belajar secara efisien dan memperoleh skor yang tinggi dalam sains.

Indikator untuk mengukur kemampuan SRL matematika siswa dalam penelitian ini menggunakan indikator SRL adalah sebagai berikut: (1) Menunjukkan insiatif dalam belajar matematika;(2) Mendiagnosis kebutuhan dalam belajar matematika; (3) Menetapkan target/tujuan belajar;(4) Memonitor, mengatur dan mengontrol belajar; (5) Memandang kesulitan sebagai tantangan;(6) Memanfaatkan dan mencari sumber belajar yang relevan;(7) Memilih dan menerapkan strategi belajar; (8) Mengevaluasi proses dan hasil belajar; dan (9) Yakin tentang dirinya sendiri (self Efficacy) (Sumarmo, 2013). 


\section{METODE PENELITIAN}

Subjek penelitian ini adalah siswa kelas VIII D sebanyak 35 siswa, pada salah satu SMP di Kabupaten Bandung Barat tahun ajaran 2013/2014. Dalam penelitian ini siswa memperoleh pembelajaran menggunakan model Lerning Cycle $5 \mathrm{E}$.

Pengumpulan data dilakukan pada setiap kegiatan siswa dan situasi yang berkaitan dengan penelitian menggunakan instrumen berupa soal tes kemampuan koneksi matematis, sklala SRL matematika siswa dan lembar observasi. Hal yang perlu diperhatikan dalam mengumpulkan data diantaranya yaitu menentukan sumber data, jenis data, teknik pengumpulan, dan instrumen yang digunakan. Teknik pengumpulan data secara lengkap disajikan pada tabel berikut.

Tabel 1.

Teknik Pengumpulan Data

\begin{tabular}{|c|c|c|c|c|}
\hline No & $\begin{array}{c}\text { Sumber } \\
\text { Data }\end{array}$ & Jenis Data & $\begin{array}{c}\text { Teknik } \\
\text { Pengumpulan }\end{array}$ & Instrumen \\
\hline 1 & Siswa & $\begin{array}{l}\text { Kemampuan akhir } \\
\text { koneksi matematis } \\
\text { siswa }\end{array}$ & $\begin{array}{l}\text { Tes akhir } \\
\text { (postes) }\end{array}$ & $\begin{array}{l}\text { Butir soal uraian } \\
\text { yang memuat } \\
\text { indikator } \\
\text { kemampuan } \\
\text { koneksi matematis. }\end{array}$ \\
\hline 2 & Siswa & $\begin{array}{l}\text { SRL matematika } \\
\text { siswa }\end{array}$ & $\begin{array}{l}\text { Pemberian } \\
\text { skala SRL }\end{array}$ & $\begin{array}{l}\text { Skala berupa daftar } \\
\text { pernyataan yang } \\
\text { memuat indikator } \\
\text { SRL. }\end{array}$ \\
\hline
\end{tabular}

Teknik analisis data menggunakan uji korelasi antara kemampuan koneksi matematis dan self-regulated learning matematika siswa. Data kemampuan koneksi matematis merupakan data interval, sedangkan data skala SRL, pada awalnya merupakan data ordinal namun data skala SRL tersebut ditransformasi menggunakan menjadi data ordinal menggunakan bantuan software Method of Successive Interval (MSI) terlebih dahulu, kemudian dilakukan uji normalitas untuk kedua data. Jika kedua data tersebut berdistribusi normal, maka uji asosiasi yang digunakan adalah uji korelasi Pearson, namun bila data tidak berdistribusi normal, maka dapat dilakukan dengan uji korelasi Spearman rho atau Kendall. Untuk mengetahui criteria koefisien korelasi yang disampaikan oleh Suherman\& Sukjaya(1990) sebagaimana tertera dalam tabel berikut: 


\section{Tabel 2}

Interpretasi Nilai Koefisien Korelasi $\mathbf{r}_{\mathrm{xy}}$

$\begin{array}{cc}\text { Koefisien Korelasi } & \text { Interpretasi } \\ 0,90 \leq r_{x y} \leq 1 & \text { Sangat Tinggi } \\ 0,70 \leq r_{x y}<0,90 & \text { Tinggi } \\ 0,40 \leq r_{x y}<0,70 & \text { Cukup } \\ 0,20 \leq r_{x y}<0,40 & \text { Rendah } \\ 0,00 \leq r_{x y}<0,20 & \text { Sangat Rendah } \\ r_{x y}<0,00 & \text { Tidak Valid }\end{array}$

HASIL PENELITIAN DAN PEMBAHASAN

\section{Hasil Penelitian}

Data kemampuan koneksi matematis diperoleh melalui pemberian tes kemampuan koneksi matematis yang memuat indikator kemampuan koneksi matematis pada akhir pembelajaran (postes), untuk data SRL matematika siswa diperoleh melalui pemberian skala SRL pada akhir pembelajaran.Berdasarkan hasil postes dianalisis dengan pemberian skor sesuai dengan pedoman penskoran untuk tes kemampuan koneksi matematis, sedangkan untuk data SRL matematika siswa menggunakan penskoran skala likert. Rerata skor kemampuan koneksi matematis dan SRL yang diperoleh merupakan gambaran kemampuan koneksi matemaris dan SRL matematika siswa yang memperoleh pembelajaran LC 5E. Berikut ini merupakan deskripsi data hasil postes kemampuan koneksi matematis dan SRL matematika siswa pada kelas LC $5 \mathrm{E}$.

Tabel 3

Statistik Deskriptif Data Kemampuan Koneksi Matematis dan SRL Matematika Siswa

\begin{tabular}{cccccc}
\hline Data & $\begin{array}{c}\text { Skor } \\
\text { Ideal }\end{array}$ & $\bar{x}$ & SD & $\boldsymbol{x}_{\text {min }}$ & $\boldsymbol{x}_{\text {maks }}$ \\
\hline $\begin{array}{c}\text { Kemampuan } \\
\text { Koneksi } \\
\text { Matematis }\end{array}$ & 12 & 6,6 & 1,63 & 3,00 & 11,00 \\
SRL Matematika & 150 & 89,2 & 1,22 & 47 & 110 \\
\hline
\end{tabular}


Tabel 4

Klasifikasi Skor Rerata SRL Matematika Siswa

\begin{tabular}{lcc}
\hline \multirow{2}{*}{ Indikator } & \multicolumn{2}{c}{ Kelas LC 5E } \\
& $\overline{\boldsymbol{x}}$ & Klasifikasi \\
\hline Indikator 1 & 3,04 & Positif \\
Indikator 2 & 3,35 & Positif \\
Indikator 3 & 3,07 & Positif \\
Indikator 4 & 3,06 & Positif \\
Indikator 5 & 3,14 & Positif \\
Indikator 6 & 2,54 & Negatif \\
Indikator 7 & 3,21 & Positif \\
Indikator 8 & 3,42 & Positif \\
Indikator 9 & 2,78 & Negatif \\
\hline
\end{tabular}

Untuk mengetahui adanya hubungan antara kemampuan koneksi matematis matematis dan SRL matematika siswa yang menggunakan pembelajaran learning cycle 5Edilakukan uji korelasi antara kemampuan koneksi matematis dan skala SRL.Sebelum melakukan uji korelasi terhadap kemampuan koneksi matematis dan skala SRL, terlebih dahulu dilakukan uji normalitas. Rumusan hipotesis untuk menguji data kemampuan koneksi matematis dan skala SRL adalah sebagai berikut:
$\mathrm{H}_{\mathrm{o}}$ : Data sampel dari populasi berdistribusi normal

$\mathrm{H}_{1}$ : Data sampel dari populasi tidak berdistribusi normal

Uji normalitas dilakukan dengan uji kormogorov-smirnov, dengan kriteria pengujian, jika nilai probabilitas (sig.) $>\alpha=0,05$ maka $\mathrm{H}_{\mathrm{o}}$ diterima, sedangkan jika sebaliknya maka $\mathrm{H}_{\mathrm{o}}$ ditolak. Hasil perhitungan uji normalitas data kemampuan koneksi matematis dan SRL mtematika siswa dapat dilihat pada Tabel 3 di bawah ini.

Tabel 5

Uji Normalitas Skor Kemampuan Koneksi Matematis dan SRL

\begin{tabular}{lccl}
\hline \multicolumn{1}{c}{ Data } & \multicolumn{2}{c}{ Shapiro-Wilk } & \multirow{2}{*}{ Kesimpulan } \\
& N & Sig. & \\
\hline Kemampuan & 35 & 0,019 & $\mathrm{H}_{\mathrm{o}}$ ditolak \\
Koneksi Matematis & 35 & 0,036 & $\mathrm{H}_{\mathrm{o}}$ ditolak \\
SRL Matematika & &
\end{tabular}



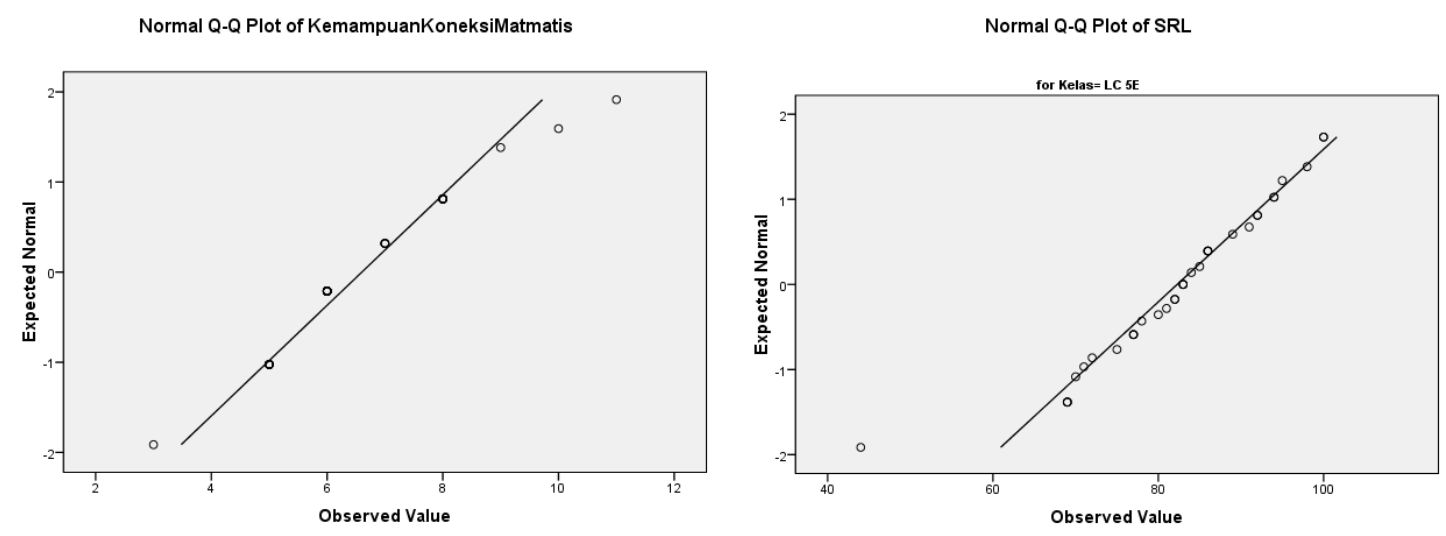

Berdasarkan Tabel 3 dan Tabel 4 koneksi matematis dengan SRL matematika siswa

di atas, hasil uji normalitas kemampuan koneksi matematis dan SRL siswa memiliki nilai signifikansi lebih kecil dari 0,05 ini berarti $\mathrm{H}_{\mathrm{o}}$ ditolak sehingga dapat disimpulkan bahwa data kemampuan koneksi dan data gain SRL pada kelompok siswa yang menggunakan pembelajaran $L C$ $5 E$ tidak berdistribusi normal. Selanjutnya akan dilakukan uji korelasi antara peningkatan kemampuan koneksi matematis dan SRL matematika siswa. Hipotesis penelitian yang diuji adalah sebagai berikut:

$\mathrm{H}_{\mathrm{o}}$ : Tidak terdapat hubungan yang signifikan antara kemampuan
$\mathrm{H}_{1}$ : Terdapat hubungan yang signifikan antara kemampuan koneksi matematis dengan SRL matematika siswa

Dikarenakan data kemampuan koneksi matematis dengan SRL matematika siswa tidak berdistribusi normal, maka selanjutnya dilakukan uji korelasi Spearman rho. Dengan kriteria pengujian, jika nilai

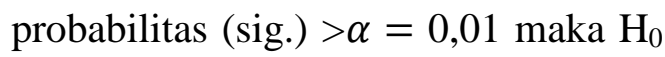
diterima, sedangkan jika sebaliknya maka $\mathrm{H}_{1}$ ditolak. Hasil perhitungan uji korelasi dapat dilihat pada Tabel 5 berikut:

Tabel 6

Uji Korelasi Kemampuan Koneksi Matematis dengan SRL Matematika Siswa

\begin{tabular}{cccccc}
\hline & Korelasi & Spearman rho & Sig. & Ket. & Kesimpulan \\
\hline \multirow{4}{*}{ Postes } & Kemampuan Koneksi & & & & \\
Matematis & 0,737 & 0,000 & $\mathrm{H}_{\mathrm{o}}$ & Terdapat \\
& SRL Matematika & & & & ditolak \\
Siswa & & & & & \\
& & & & & \\
\hline
\end{tabular}

Pada Tabel 5.di atas terlihat bahwa nilai sig. $=0,000<0,01$, sehingga $\mathrm{H}_{0}$ ditolak dengan kata lain
$\mathrm{H}_{0}$ diterima, sehingga dapat disimpulkan bahwa terdapat hubungan yang signifikan antara kemampuan 
koneksi matematis dengan SRL matematika siswa. Besarnya koefisien korelasi antara kemampuan koneksi matematis dengan SRL matematika siswa 0,737 termasuk dalam kategori korelasi tinggi.

\section{Pembahasan}

Pembelajaran LC 5E memfasilitasi siswa mengembangkan SRL matematika siswa dikarenakan pada setiap tahap LC 5E menuntut partisipasi aktif siswa dalam aktivitas pembelajaran dan belajar disiplin dalam memanfaatkan waktu yang dibatasi dalam setiap tahap LC 5E. Misalnya, pada tahap engagement guru menuntun siswa untuk mengetahui tujuan pembelajaran yang akan dilaksanakan. Selanjutnya, pada tahap exploration siswa berdiskusi dengan dalam kelompok, berusaha bekerja sama dalam kelompok untuk menemukan suatu konsep sehingga mereka mengetahui tujuan yang harus mereka capai yaitu menemukan suatu konsep yang harus dipresentasikan di depan kelas pada tahap explanation dan konsep tersebut digunakan untuk menyelesaikan masalah dalam bentuk soal pada tahap elaboration.

Proses penciptaan koneksi dalam pembelajaran matematika dapat dilakukan melalui LC 5E, yaitu pada tahap engagement, exploration, dan elaboration. Tahap engagement merupakan tahap penciptaan koneksi materi yang akan dipelajari dengan masalah kehidupan sehari-hari dan tahap exploration, siswa mengaplikasikan konsep/pengetahuan yang diperoleh dalam proses elboration dengan cara mengerjakan soal kontekstual. Selain itu, dalam proses eksplorasi juga terjadi proses penciptaan koneksi, misalnya dalam eksplorasi dalam LKS 9 dan LKS 10 terjadi proses koneksi dengan menggunakan rumus Teorema Pythagoras dalam menemukan rumus panjang garis singgung persekutuan luar dan panjang garis singgung persekutuan dalam. Hal ini menjadi dasar bahwa pembelajaran LC 5E dapat mengembangkan kemampuan koneksi matematis siswa. 


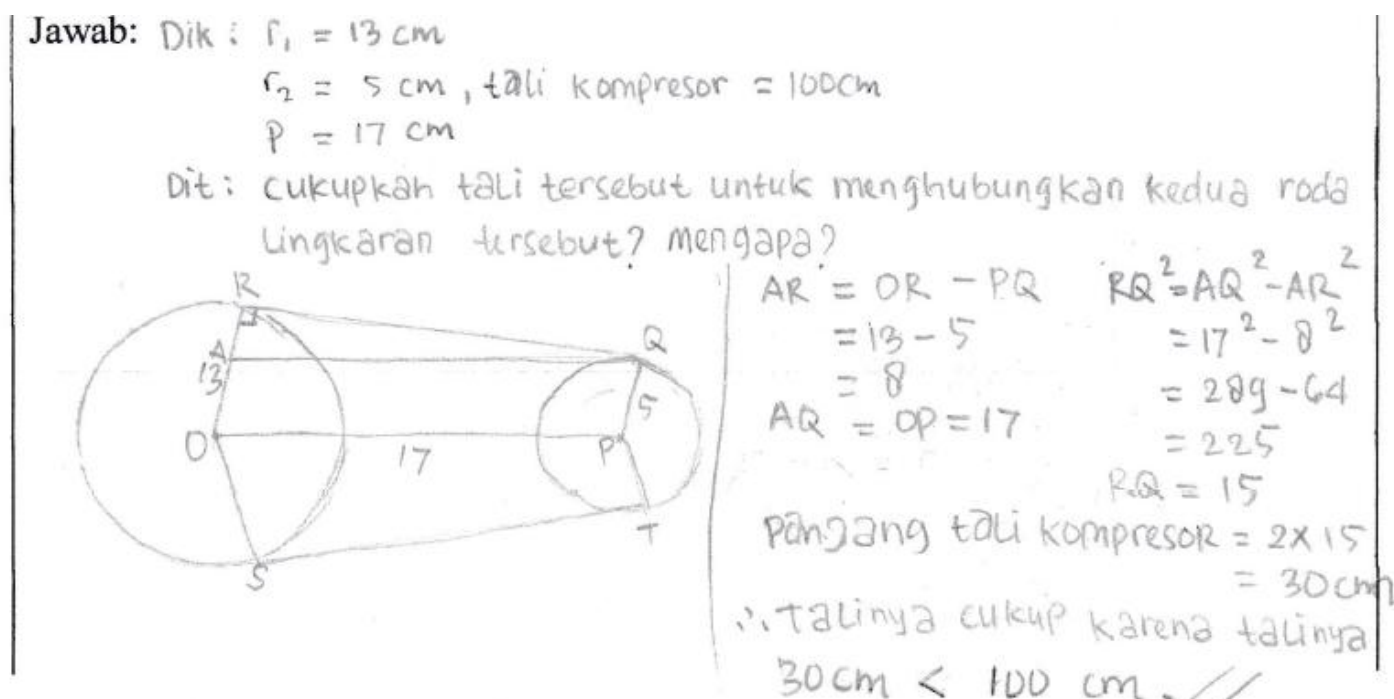

Gambar 1

Jawaban Siswa pada Soal Kemampuan Koneksi Matematis

Hasil pekerjaan siswa pada Gambar 1, menunjukkan bahwa siswa menggunakan Teorema Pythagoras dalam menyelesaikan soal garis singgung persekutuan luar dua lingkaran. Meskipun siswa tersebut tidak menyelesaikan soal tersebut dengan benar, karena seharusnya siswa tersebut juga menghitung panjang busur RS dan QT untuk menghitung panjang tali kompresor, siswa tersebut mampu menunjukkan bahwa untuk menyelesaikan soal garis singgung persekutuan luar dua lingkaran tidak secara langsung menggunakan rumus garis singgung dua lingkaran yang juga menggunakan konsep Teorema Pythagoras.

Hal tersebut menunjukkan bahwa siswa tidak bergantung pada rumus yang telah dipelajari. Siswa tersebut ada kemungkinan lupa terhadap rumus panjang garis persekutuan luar dua lingkaran, akan tetapi siswa tersebut mengingat proses mengkonstruksi rumus panjang garis persekutuan luar dua lingkaran pada saat pengerjaan LKS yang menggunakan konsep Teorema Pythagoras.

Hasil pencapaian kemampuan koneksi matematis yang diperoleh siswa belum maksimal, hal ini dapat dilihat dari rerata postes kemampuan koneksi matematis. Penyebabnya, siswa kurang memiliki pengetahuan prasyarat yang baik, kurang mengenali soal yang berkaitan dengan pokok bahasan tertentu. Rerata nilai KAM yang diperolah dari hasil ulangan harian Bentuk Aljabar dan Teorema Pythagoras menunjukkan masih dibawah kriteria ketuntasan minimal (KKM). Soal-soal ulangan harian yang diberikan mengukur kemampuan pemahaman matematis siswa menunjukkan hasil rerata yang belum maksimal, sehingga hal tersebut diduga menjadi salah satu faktor hasil kemampuan koneksi matematis siswa belum maksimal. Penyebab lainnya karena siswa terbiasa menyelesaikan 
soal yang hanya memerlukan satu konsep matematika yang sedang dipelajari tanpa dihubungkan dengan konsep matematika yang telah dipelajari sebelumnya. Hal ini menyebabkan siswa tidak dapat menyelesaikan soal koneksi matematis yang menuntut siswa menghubungkan dengan konsep matematika yang telah dipelajari siswa dalam penyelesaiannya. Selain itu, waktu pelaksanaan pembelajaran tidak dimanfaatkan siswa secara maksimal, misalnya pada saat pergantian jam pelajaran guru telah meminta siswa untuk duduk dalam kelompoknya, akan tetapi saat guru masuk kelas siswa belum berkumpul dalam kelompok masing-masing. Saat pergantian jam pelajaran dan pada saat pembelajaran berlangsung setiap pertemuan selalu ada beberapa siswa yang izin ke kamar kecil. Hal ini menyebabkan berkurangnya waktu pembelajaran dan beberapa siswa tidak mengikuti pembelajaran secara maksimal.

Dalam hal ini siswa yang memperoleh skor SRL terendah di kelas LC 5E merupakan siswa kategori rendah dalam pencapaian kemampuan koneksi matematisnya, selama proses pembelajaran tidak aktif dalam diskusi kelompok maupun diskusi kelas, sering melamun dan terlihat tidak termotivasi untuk belajar, saat guru melakukan pendekatan siswa tersebut cenderung tertutup dan siswa tersebut tidak mau bersosialisasi dengan siswa lainnya. Sehingga, dimungkinkan siswa tersebut memiliki SRL yang rendah. Hal ini sejalan dengan yang dikemukakan oleh Zimmerman (Tilamann \& Weiss, 2000) siswa yang memiliki SRL yang tinggi, mereka memiliki kesadaran berpikir, penggunaan strategi dan motivasi intrinsik yang terpelihara sehingga membantunya untuk menghindari gangguan internal dan eksternal, menjaga konsentrasi, usaha, dan motivasi mereka ketika melakukan tugas akademik.

Ditinjau berdasarkan indikator SRL, rerata SRL siswa di kelas LC 5E pada indikator 6 yaitu memanfaatkan dan mencari sumber belajar yang relevan; dan indikator 9 yaitu yakin tentang dirinya sendiri, masih pada kategori negatif. Rendahnya SRL siswa kelas LC 5E pada indikator 6, terjadi dikarenakan tahapan LC 5E yang memerlukan banyak waktu maka siswa cenderung tidak memeriksa kembali tugas yang telah dikerjakan. Selain itu, kepemilikan sumber belajar (buku paket) dikelas LC 5E tidak marata, masih banyak siswa yang tidak memiliki/membawa buku paket matematika pada saat pembelajaran. Sebagaian siswa di kelas LC 5E tidak mempunyai buku paket matematika sehingga siswa belajar hanya dengan mengandalkan pengetahuan yang telah dipelajari sebelumnya dan mengikuti langkah-langkah yang terdapat di bahan ajar (LKS) LC 5E dalam mencari dan menemukan kembali suatu konsep, sesekali mereka mencari sumber di internet melalui handphone.

Rendahnya SRL matematika siswa kelas LC 5E pada indikator 6 yaitu "yakin tentang dirinya sendiri", 
dikarenakan proses pembelajaran yang sebelumnya menggunakan ekspositori, cenderung membuat siswa kurang percaya diri dalam mengungkapkan ide dan pendapat mereka dalam diskusi dan tidak semua siswa berani mengungkapkan ide dan pendapat atas kemauan sendiri, mereka harus terlebih dahulu ditanya dan diminta untuk mengungkapkan ide dan pendapatnya. Seringkali kelompok yang mempresentasikan hasil eksplorasinya bertanya terlebih dahulu kepada guru mengenai hasil eksplorasinya sudah benar atau belum, siswa yang mempresentasikan hasil eksplorasi kelompoknya juga harus ditunjuk terlebih dahulu dan harus ditemani oleh teman satu kelompoknya dan dimotivasi oleh guru terlebih dahulu. Hal tersebut menunjukkan bahwa siswa kelas LC $5 \mathrm{E}$ masih rendah pada indikator yakin tentang dirinya sendiri. Temuan ini sejalan dengan penelitian yang dilakukan oleh De Corte et al. (Izzati, 2012) yang melaporkan bahwa adanya kelemahan mendasar pada komponenkomponen keterampilan kemandirian belajar bagi banyak siswa, salah satunya kelemahan pada kepercayaan diri siswa.

Berdasarkan analisis hubungan antara kemampuan koneksi matematis dan SRL matematika siswa menunjukkan terdapat hubungan dengan kategori korelasi tinggi. Hal ini berarti bahwa siswa dengan kemampuan koneksi matematis tinggi mempunyai SRL matematika yang tinggi juga dan sebaliknya siswa dengan koneksi matematis rendah mempunyai SRL matematika yang rendah juga. Hal ini sesuai dengan yang diungkapkan Sumarmo (2013) bahwa SRL merupakan proses perancangan dan pemantauan diri yang seksama terhadap proses kognitif dan afektif dalam menyelesaikan suatu tugas akademik. Apabila siswa mempunyai SRL yang tinggi, siswa tersebut cenderung belajar lebih baik. Hal ini didukung oleh hasil penelitian Hargis (Sumarmo, 2013) bahwa individu yang memiliki SRL cenderung belajar lebih baik, mampu memantau, mengevaluasi dan mengatur belajarnya secara efektif, menghemat waktu dalam menyelesaikan tugasnya, mengatur kegiatan dan waktu belajar secara efisien dan memperoleh skor yang tinggi dalam sains.

Melalui model pembelajaran LC 5E adalah model pembelajaran yang memberikan kesempatan kepada siswa untuk mengoptimalkan kemampuan matematis siswa dalam proses pembelajaran. Model pembelajaran LC 5E terdapat tahap-tahap kegiatan (tahap) yang diorganisasikan sedemikian rupa, sehingga siswa dapat mencapai kompetensi-kompetensi yang menjadi tujuan pembelajaran.Sehingga siswa yang memiliki SRL matematika yang baik, pencapaian kemampuan koneksi matematisnya juga baik dan sebaliknya siswa yang dengan SRL matematika yang kurang, pencapaian kemampuan koneksi matematisnya juga kurang baik. 


\section{KESIMPULAN DAN SARAN}

\section{Kesimpulan}

Hasil analisis data menunjukkan bahwa terdapat asosiasi antara kemampuan koneksi matematis dan self-regulated learning(SRL) matematika siswa. Besarnya koefisien korelasi antara kemampuan koneksi matematis dengan SRL matematika siswa 0,737 termasuk dalam kategori korelasi tinggi.

\section{Saran}

Berdasarkan kesimpulan dan temuan kajian asosiasi antara kemampuan koneksi matematis dan self-regulated learning matematika siswa, disarankan kepada pendidik bahwa penting untuk mengembangkan kemampuan koneksi matematis tidak dapat lepas dari pengembangan selfregulated learning matematika siswa.

\section{DAFTAR PUSTAKA}

Bybee, R. W., et al. (2006). The BSCS 5E Instructional Model: Origins, Effectiveness, and Applications. [Online]. Tersedia: http://www.bscs.org/pdf/bscs5ee xemummary.pdf. [12 Juni 2013]

Darr, C. \& Fisher, J.(2004). SelfRegulated Learning in Mathematics Class. Paper presented at NZARE Conference, Turning the Kaleidoscope, Wellington, 24-26 November, 2004. [Online]. Tersedia:

http://www.nzcer.org.nz/system/ files/13903.pdf [19Maret 2013].

Ergin, I. (2012). Constructivist Approach Based 5E model and Usability Instructional
Physiscs.Lat. Am. J. Phys. Educ. Vol. 6, No. 1, 14-20.

Lorsbach, A. W. (2002). The Learning Cycle as A tool for Planning Science Instruction. [Online]. Tersedia:

(http://www.coe.ilstu.edu/scienc eed/lorsbach/257lrcy.html). [12 Juni 2013].

Madu, B. C., \& Amaechi, C. C., (2012). Effect of Five-Step Learning Cycle Model on Students' Understanding of Concepts Related to Elasticity. Journal of Education and Practice. Volume 3, No. 9, 2012.[Online].

Tersedia:http://www.iiste.org/Jo urnals/index.php/JEP/article/vie wFile/2418/2434 [12 Juni 2013]

National of Council Teacher of Mathematics.(1989). Principle and Standards for School Mathematics. Reston, VA: NCTM.

Santrock, J.W. (2007). Educational Pyschology $2^{\text {nd }}$ Edition. Jakarta: Fajar Interpratama Offset.

Schunk, D.H. (2002). Self-Regulated Through Goal Setting. (http://www.ericdigests.org). [12 November 2013].

Suherman, E \& Sukjaya, Y. (1990).Petunjuk Praktis untuk Melaksanakan Evaluasi Pendidikan Matematika. Bandung: Wijayakusuma.

Sumarmo, U. (2013). Kumpulan Makalah Berpikir dan Disposisi Matematik serta Pembelajarannya. Bandung: FMIPA UPI 
Tilamann, K.J \& Weiss, M. (2000).Self-Regulated Learning as Cross-Curricular Competence (PISA). [Online]. Tersedia:

http://www.pisa.no/pdf/turmoion ste2004.pdf. $\quad[12$ November 2013]. 